\title{
17. INTERSTITIAL WATER CHEMISTRY, LEG 17
}

\author{
B. J. Presley and J. H. Culp, Department of Oceanography, Texas A\&M University, College Station, Texas \\ and \\ C. Petrowski and I. R. Kaplan, Department of Geology, University of California, Los Angeles, California
}

\section{INTRODUCTION AND PROCEDURES}

Leg 17 of the Deep sea Drilling Project began at Honolulu, Hawaii, proceeded on a large loop through the Line Islands to east of the Marshall Islands, then returned to Honolulu. Ten holes were drilled at eight different sites along the way, usually to a basaltic "basement." The lithology of the cored sediment was complex, with radiolarian-rich brown clays common. Abundant calcareous fossil remains were also found, as were chert layers, volcanic debris, and turbidite layers.

Squeezed and filtered pore water from seven sites was received at Texas $A \& M$, and heat sealed into Manheim-type containers. Water samples heat sealed into plastic syringes were also sent to UCLA for $\mathrm{CO}_{2}$ and carbon isotope work. The work at Texas A\&M consisted of determining major cations, $\mathrm{Cl}, \mathrm{Br}, \mathrm{B}, \mathrm{NH}_{3} \mathrm{Mn}$, and $\mathrm{Si}$, on the approximately 3-ml samples. This small sample size precluded any duplicate analyses and lead to some scatter in the data, but did not obscure any of the trends.

The analytical procedures used by both groups are essentially the same as those described previously (Presley, 1971; Presley and Claypool, 1971), but small modifications have been made in order to facilitate sample handling.

\section{RESULTS AND DISCUSSION}

All results we obtained from the interstitial water sample analyses are given in Table 1.

On all previous legs, the $\mathrm{Cl}$ and $\mathrm{Br}$ content of the pore water has been close to that of average sea water, except for those locations where evaporites were known or suspected to be present in the sedimentary column. A second exception is that a few near-shore holes have encountered fresher water at depth, apparently due to an influx of continental fresh water. Only one of the Leg 17 samples gave what we would consider to be an abnormal $\mathrm{Cl}$ value, that occurred at about 87 meters deep at Site 164, in what was described as a brown zeolitic clay of possible Upper Cretaceous age. We have no other data to confirm the low $\mathrm{Cl}$ value found here, but the $\mathrm{Br}$ value which is determined independently is also low. In fact, the $\mathrm{Cl} / \mathrm{Br}$ ratio in this sample is near normal. We have no explanation for these unusual values at this time, but they seem to be real, judging by a similar occurrence we noted at Site 163 (Presley et al., in press). The other $\mathrm{Br}$ values show some scatter, but only in a few cases does this result in a $\mathrm{Cl} / \mathrm{Br}$ ratio which differs from that in sea water by more than $5 \%$.

Boron concentrations for samples from previous legs have generally not varied greatly from the normal sea-water value, and this is also true for Leg 17 samples. No trend with depth is apparent that would suggest either uptake or release by solid phases, except possibly at Site 164 where a low value was found at the bottom.

Dissolved silica concentrations are generally high, as would be expected in view of the abundance of amorphous biogenic silica. It is interesting to note, however, that in some cases there is as much as $30 \%$ variation in the silica concentration from site to site or with depth at a given site, even when the lithologic description of the sediments is identical. Part of this variation might be caused by differential warming of the sediment after collection and before and during squeezing, but in some cases smooth trends with depth make this seem unlikely. The bottom two samples from Hole 171 are interesting in that the dissolved $\mathrm{Si}$ concentration is extremely high at 223 meters deep, where chert is first reported, but at 240 meters deep, with chert still present, the concentration is much lower. Perhaps this indicates that chert becomes less soluble as it matures.

Ammonia concentrations were much lower in these pelagic sediments than those we find in near-shore locations, but were still measurable in all samples, and were considerably higher than those in sea water. There seems to be a definite enrichment at intermediate depths at Site 165, and it seems likely that organic matter is continuing to degrade, even at these depths.

The $\mathrm{CO}_{2}$ concentrations are similar to those of ammonia in that a slight enrichment over the normal sea-water value is common, but no unusually high enrichments such as are found in near-shore sediments were observed. There is some tendency for $\mathrm{CO}_{2}$ depletion with depth, but the trend is not nearly so clear as it has been on many previous legs.

The relatively high $\mathrm{CO}_{2}$ concentrations near the bottom of Hole 171, and especially the isotopically light nature of the $\mathrm{CO}_{2}$ carbon, is strong evidence that organic matter is continuing to degrade at these depths. The carbon isotope values are, in fact, generally lower in Leg 17 samples than values obtained for most other pelagic sediments studied. Apparently $\mathrm{CaCO}_{3}$ precipitation also occurs and results in maintaining dissolved $\mathrm{CO}_{2}$ concentration near the level of sea water. In near-shore areas, on the other hand, we often find high concentrations of total dissolved $\mathrm{CO}_{2}$, and consequently high supersaturation with respect to $\mathrm{CaCO}_{3}$ (Presley and Kaplan, 1968).

Manganese behaved in a manner expected from previous work. That is, its dissolved concentration was highly variable and does not seem to be related to any of the other measured parameters in solution. The values were generally somewhat lower than those found on most previous legs, or perhaps more accurately, there were more samples below our detection limit than we have found on previous legs. 
TABLE 1

Selected Major and Minor Constituents and $\delta C^{13}$, Interstitial Water, Leg 17

\begin{tabular}{|c|c|c|c|c|c|c|c|c|c|c|}
\hline $\begin{array}{l}\text { Sample } \\
\text { Number }\end{array}$ & $\begin{array}{c}\text { Depth } \\
(\mathrm{m})\end{array}$ & Age and Description of Sediment ${ }^{c}$ & $\begin{array}{c}\mathrm{Cl} \\
(\mathrm{g} / \mathrm{Kg})\end{array}$ & $\begin{array}{c}\mathrm{Br} \\
(\mathrm{mg} / \mathrm{Kg})\end{array}$ & $\begin{array}{c}\mathrm{B} \\
(\mathrm{mg} / \mathrm{Kg})\end{array}$ & $\begin{array}{c}\mathrm{Si} \\
(\mathrm{mg} / \mathrm{Kg})\end{array}$ & $\begin{array}{c}\mathrm{NH}_{3} \\
(\mathrm{mg} / \mathrm{Kg})\end{array}$ & $\begin{array}{c}\mathrm{Mn} \\
(\mathrm{mg} / \mathrm{Kg})\end{array}$ & $\underset{(\mathrm{mM} / \mathrm{Kg})}{\Sigma \mathrm{CO}_{2}}$ & $\begin{array}{c}\delta \mathrm{C}^{13} \\
\left(\Sigma \mathrm{CO}_{2}\right) \\
(\% \circ \mathrm{PDB})\end{array}$ \\
\hline $164-1-6$ & 47 & L. Miocene; brown zeolitic clay & 19.4 & 66 & 4.5 & 13.6 & 0.2 & 0.05 & 3.0 & -14.0 \\
\hline $164-7-2$ & 87 & U. Cretaceous (?); same as above & 17.6 & 58 & 5.3 & 17.4 & 0.3 & 0.05 & 2.9 & -5.4 \\
\hline $164-19-4$ & 202 & U. Cretaceous (?); same as above & 19.0 & 63 & 2.2 & 23.8 & 1.9 & 3.6 & 1.7 & -2.1 \\
\hline $165-1-3$ & 5 & L. Miocene; $\mathrm{CaCO}_{3}$ micrite ooze & 19.3 & 67 & 5.3 & 14.3 & 0.8 & $<0.05$ & 2.2 & -8.3 \\
\hline $165 \mathrm{~A}-1-5$ & 12 & U. Oligocene; $\mathrm{CaCO}_{3}$ ooze & 19.3 & 65 & 5.0 & 14.4 & 0.3 & $<0.05$ & 2.9 & -12.2 \\
\hline $165 \mathrm{~A}-5-4$ & 86 & L. Oligocene; $\mathrm{CaCO}_{3}-\mathrm{SiO}_{2}$ ooze & 19.5 & 67 & 4.7 & 23.1 & 4.1 & $<0.05$ & 3.1 & - \\
\hline $165 \mathrm{~A}-6-5$ & 134 & L. Oligocene; $\mathrm{CaCO}_{3}-\mathrm{SiO}_{2}$ ooze & - & - & - & 27.6 & 4.7 & 1.1 & 3.1 & -3.4 \\
\hline $165 \mathrm{~A}-8-3$ & 150 & U. Eocene; $\mathrm{SiO}_{2}$ ooze & 19.4 & 71 & 4.7 & 30.7 & 0.4 & 1.1 & 2.8 & +0.3 \\
\hline $165 \mathrm{~A}-10-6$ & 211 & M. Eocene; $\mathrm{SiO}_{2}$ ooze & 19.3 & 70 & 4.4 & 29.2 & 2.1 & 1.2 & 2.9 & -0.9 \\
\hline $166-2-5$ & 10 & U. Miocene; $\mathrm{SiO}_{2}$ ooze & 19.2 & 69 & 4.6 & 17.1 & 0.3 & $<0.05$ & 3.1 & -9.6 \\
\hline $166-7-4$ & 70 & L. Miocene; $\mathrm{SiO}_{2}$ ooze with $\mathrm{CaCO}_{3}$ & 19.6 & 66 & 4.8 & 23.6 & 3.8 & $<0.05$ & 2.9 & -5.9 \\
\hline $166-9-6$ & 111 & U. Oligocene; $\mathrm{SiO}_{2}$ ooze & 19.5 & 69 & - & 22.5 & 1.9 & $<0.05$ & 1.3 & -5.6 \\
\hline $166-12-5$ & 160 & U. Eocene; $\mathrm{SiO}_{2}$ ooze & 19.5 & 64 & 4.4 & 23.6 & 2.6 & $<0.05$ & 2.9 & - \\
\hline $166-20-5$ & 227 & L. Cretaceous; brown Pelagic mud & 19.1 & 68 & 4.7 & 17.8 & 0.1 & 0.05 & 1.5 & - \\
\hline $167-5-5$ & 109 & M. Miocene; $\mathrm{CaCO}_{3}$ ooze & 19.5 & 69 & 5.7 & 18.9 & 1.0 & $<0.05$ & 3.0 & -4.2 \\
\hline $167-12-5$ & 340 & U. Oligocene; chalk ooze & 19.8 & 70 & 4.6 & 27.0 & 1.7 & $<0.05$ & 4.5 & - \\
\hline $167-23-5$ & 525 & L. Oligocene; chalk & 19.9 & 70 & 4.7 & 31.1 & 2.6 & $<0.05$ & 1.5 & -6.5 \\
\hline $167-28-2$ & 558 & U. Eocene; chalk with rads & 19.3 & 70 & 4.7 & 32.0 & 0.4 & $<0.05$ & 1.7 & -10.9 \\
\hline $168-4-2$ & 33 & $\begin{array}{l}\text { L. Oligocene (?); brown chert } \\
\text { and clay }\end{array}$ & 19.4 & 67 & 6.1 & 20.0 & 2.5 & 0.10 & 2.7 & -3.9 \\
\hline $170-6-4$ & 107 & Campanian; chalk & 19.2 & 67 & 4.1 & 16.4 & 1.4 & 3.9 & 2.2 & -8.0 \\
\hline $171-2-3$ & 20 & M. Miocene; foram ooze & 19.3 & 66 & 4.4 & 14.8 & 3.3 & $<0.05$ & 2.5 & -5.1 \\
\hline $171-5-5$ & 85 & L. Oligocene; foram ooze & 19.3 & 67 & 4.4 & 15.9 & 0.9 & $<0.05$ & 3.2 & -12.2 \\
\hline $171-15-5$ & 223 & C. foram ooze and chert & 19.1 & 66 & 4.6 & 41.3 & 0.2 & $<0.05$ & 4.3 & -10.3 \\
\hline $171-17-3$ & 240 & Campanian; foram ooze and chert & 19.1 & 68 & 4.2 & 14.8 & 0.3 & $<0.05$ & 2.7 & -15.3 \\
\hline \multicolumn{3}{|c|}{ Average sea water } & 19.4 & 67 & 4.5 & $0-3$ & $0.0(?)$ & 0.0 & 2.6 & 0.0 \\
\hline
\end{tabular}

${ }^{\mathrm{a}}$ Hole, core, section.

b Depth in sediment.

cFrom preliminary hole summaries.

\section{ACKNOWLEDGMENTS}

This work was supported in part by AEC Grant AT (11-1)-34 P.A. 134 and NSF Grant GA-20715.

\section{REFERENCES}

Presley, B. J., 1971. Techniques for Analyzing Interstitial Water Samples. Part I: Determination of Selected Minor and Major Inorganic Constituents: Initial Reports of the Deep Sea Drilling Project, Volume III. Washington (U.S. Government Printing Office), p. 1749.
Presley, B. J. and G. E. Claypool, 1971. Techniques for Analyzing Interstitial Water Samples. Part II: Determination of Total Dissolved Carbonate and Carbon Isotope Ratios. Initial Reports of the Deep Sea Drilling Project, Volume II. Washington (U.S. Government Printing Office), p. 1756.

Presley, B. J., and Kaplan, I. R., 1968. Changes in Dissolved Sulfate, Calcium and Carbonate from Interstitial Water of Near-shore Sediments. Geochim. Cosmochim. Acta, v. 32, p 1037.

Presley, B. J., Petrowski, C., and Kaplan, I. R., 1973. Interstitial Water Chemistry: Deep Sea Drilling Project, Leg 16. In The Initial Report of the Deep Sea Drilling Project, Volume XVI. Washington (U. S. Government Printing Office), p. 573. 